\title{
Evaluation of information retention and adherence to treatment in patients with gestational diabetes mellitus after multidisciplinary group
}

Ana Maria da Silva Sousa ${ }^{1 *}$, Daine Fiuza², Fernanda Cristina Ferreira Mikami³ ${ }^{3}$, Karen Cristine Abrão ${ }^{4}$, Rossana Pulcinel Vieira

FRANCISCO ${ }^{5}$, Marcelo ZUGaiB ${ }^{6}$

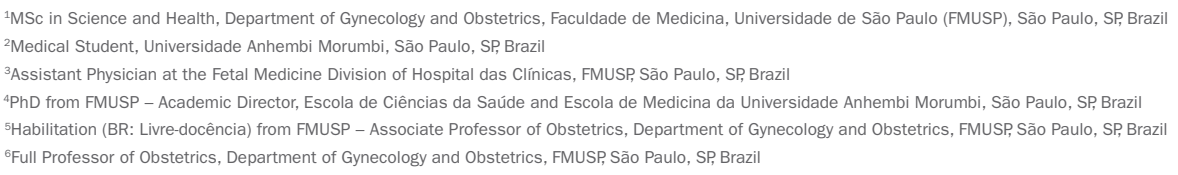

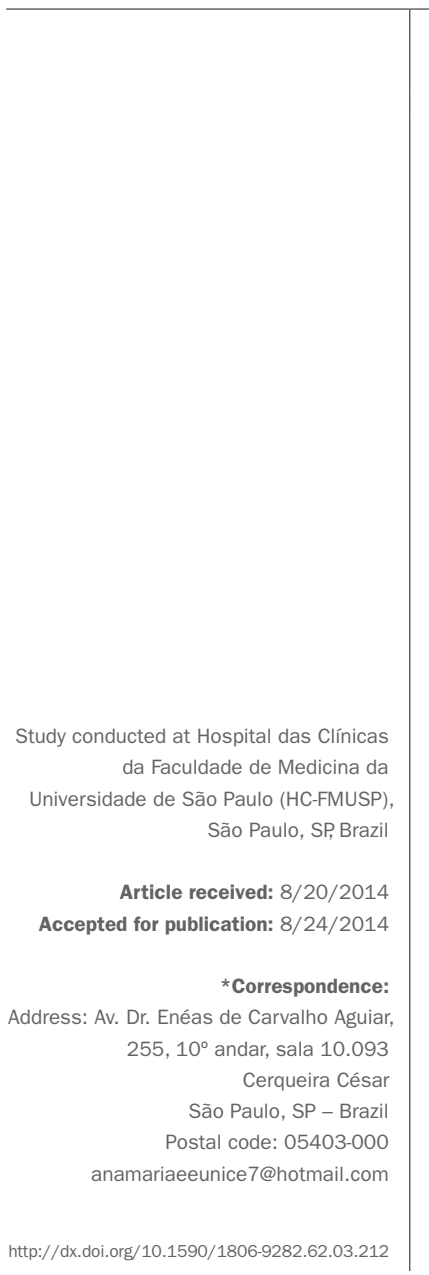

\section{SUMmARY}

Objective: To evaluate the retention of information after participation in multidisciplinary group in patients with gestational diabetes mellitus (GDM) through a phone contact.

Method: 122 pregnant women diagnosed with gestational diabetes were included. After diagnosis of gestational diabetes, the patients were referred to the multidisciplinary group where they received medical, nutrition and nursing guidelines related to the disease. After three days these patients received one telephone call from a nurse, who made the same questions regarding the information received. In the statistical analysis, results were presented as absolute and relative frequencies.

Results: Most patients 119/122 patients (97.5\%) were managing to do self glucose monitoring. Twenty-one patients (17.2\%) reported having difficulty performing the blood glucose, especially finger pricking. When questioning whether the woman was following the proposed diet, 24/122 (19.7\%) patients said they did not; the meal frequency was not reached by $23 / 122$ (18.9\%) of the women, and forty-seven (38.5\%) of the women reported having ingested sugar in the days following the guidance in multidisciplinary group.

Conclusion: Regarding the proposed treatment, there was good adherence of patients, especially in relation to blood glucose monitoring. As for nutritional control, we observed greater difficulty in following the guidelines demonstrating the need for long-term monitoring, as well as further clarification to the patients about the importance of nutrition in diabetes management.

Keywords: gestational diabetes, patient care team, blood glucose self-monitoring, food and nutritional education.

\section{INTRODUCTION}

Gestational diabetes mellitus (GDM) is defined as glucose intolerance that starts in pregnancy, excluding cases of diabetes mellitus diagnosed for the first time in pregnancy (overt diabetes) ${ }^{1,2}$ It is an important morbidity due to its significant complications for pregnant women and embryos, with estimated prevalence of 7.6 to $17.8 \%$ depending on the criteria used. ${ }^{1,3,47}$ Currently, the diagnosis of GDM is confirmed when the fasting glucose at the first prenatal consultation is between 92 and $125 \mathrm{mg} / \mathrm{dL}$ or when at least one of the glucose values in the oral glucose tolerance test of $75 \mathrm{~g}$ (OGTT-75 g) is equal to or above the reference values, which are: fasting $\geq 92 \mathrm{mg} / \mathrm{dL}, 1$ hour after glucose overload $\geq 180 \mathrm{mg} / \mathrm{dL}$ and 2 hours after $\geq 153 \mathrm{mg} / \mathrm{dL}$, which is conducted on pregnant women with a gestational age between the $24^{\text {th }}$ and $28^{\text {th }}$ week of pregnancy. ${ }^{1}$ 
The time interval between diagnosis and delivery, especially when this is established through glucose tolerance test conducted between 24 and 28 weeks is very short, requiring the patient to adapt quickly to their new condition depending significantly on their self-perception and state of health. For this reason, health education has been a proposal to improve the adherence to the treatment, although there is need to check the retention after guidance of the new knowledge. Telephone calls have been a tool in constant use for checking this result.

The aim of this study was to evaluate the retention of information by patients with GDM after participation in multidisciplinary group through telephone contact three days after the workshop.

\section{Method}

This is longitudinal study approved by the Ethics Committee for Analysis of Research Projects at the Hospital das Clínicas of the Faculdade de Medicina, Universidade de São Paulo (Comissão de Ética para Análise de Projetos de Pesquisa, CAPPesq). We assessed pregnant women with a diagnosis of GDM monitored at the Obstetric Clinic's Endocrinopathies and Gestation Sector at the Hospital das Clínicas, Faculdade de Medicina, Universidade de São Paulo (HC-FMUSP) from August 2012 to May 2014. We used the following inclusion criteria: diagnosis of GDM in the current pregnancy, participation in the multidisciplinary group and statement of informed consent given in writing. The exclusion criterion was the impossibility of telephone contact.

After the diagnosis of GDM, the patient was transferred to a multidisciplinary group to receive relevant information and guidance about the disease. Medical advice was initially given, clarifying queries and questions about GDM. Subsequently, a nutritionist provided guidance about the best diet to be followed by a pregnant women with gestational diabetes. In relation to self-monitoring of blood glucose, a nurse provided instruction and learning opportunities for the pregnant women to use the glucose meter.

The pregnant women received a telephone call three days after completion of the guidance provided by the multidisciplinary team. During the telephone contact, a questionnaire was applied to evaluate the retention of information and adherence to the proposed treatment in relation to self-monitoring of blood glucose and nutritional guidance. After application of the questionnaire and identification of the main queries and difficulties, the patient was reoriented in accordance with the necessities presented. Thus, the following variables were evaluated: able to take capillary blood glucose (yes/no), difficulty in taking capillary blood glucose (yes/no), what the difficulty was in taking the capillary blood glucose, queries about the collection of the drop of blood (yes/no), what the query about collection of the drop of blood was, queries about the operation of the glucose meter (yes/no), what the query about the operation of the glucose meter was, able to take the capillary blood glucose measurements at the correct times (yes/no), able to see the result in the glucose meter (yes/no), able to note the result on the monitoring sheet (yes/no), able to follow the diet (yes/no), able to divide up meals (yes/ no), ate sugary foods in the last few days (yes/no), what sugary food was eaten in the last few days, eaten any food which they perceived increased their blood glucose (yes/ no), what food was eaten that increased their blood glucose, level of discomfort (0 to 5), level of difficulty (0 to 5), need for any more guidance (yes/no) and what guidance was needed. Fisher's exact test was used for comparison of the categorical variables.

\section{Results}

Thirteen from the total of 135 patients included in the study were exclude due to the impossibility of telephone contact, with the final group consisting of 122 pregnant women with a diagnosis of GDM. During the telephone call, the patients were asked whether they were able to perform capillary self-monitoring of blood glucose, with the vast majority of patients saying yes: 119/122 (97.5\%). Twenty-one patients (17.2\%) reported having difficulty in performing the capillary blood glucose test. The main difficulties cited were related to the lancet and the time for conducting self-monitoring. Through the answers provided via telephone contact, the difficulty level was classified according to the intensity cited by the patient, on a scale of 0 to 5 , and only 10/122 (9\%) of the pregnant women considered it too difficult to perform capillary blood glucose test.

We also questioned the discomfort felt with the realization of capillary blood glucose, where 21/122 (19\%) of pregnant women considered the procedure very uncomfortable. As for the fact of whether there was still any doubt about the guidance provided, only $6 / 122$ (4.9\%) of the pregnant women responded yes, with the main query being about the amount of blood required for the capillary blood glucose analysis. In relation to the operation of the capillary blood glucose device, $4 / 122$ (3.3\%) of the patients reported they still had questions, the main one being related to the glucose meter battery. A small amount of patients were unable to take the capillary blood glucose at the correct times, 15/122 (12.3\%). Four patients (3.3\%) reported 
not being able to see the result of the capillary blood glucose. The majority of the patients, $97.5 \%$, managed to note down the capillary blood glucose results on the monitoring sheet for the blood glucose values obtained.

When questioning if the pregnant woman was able to follow the proposed diet, 24/122 (19.7\%) responded no; the spacing of meals was not achieved by $23 / 122(18.9 \%)$ of the pregnant women. Forty-seven (38.5\%) of the pregnant women reported having ingested sugar on the days following the orientation in the multidisciplinary group. The highest frequently cited was cake, in 17 cases. Fortysix patients (37.7\%) perceived an increase in capillary blood glucose when consuming certain foods. Cake was also the food most cited by patients who reported having perceived increased capillary blood glucose after eating.

Only $11(9 \%)$ of the pregnant women reported needing more guidance after participation in the multidisciplinary group, with the capillary blood glucose reference values as the most frequent query.

\section{Discussion}

GDM is an obstetric complication that often surprises pregnant women in the third trimester. In diabetes, the patient is usually the primary provider of care, as well as the recipient. The level of self-perception established by the patient depends to a large extent on the individual and their ability to perform activities with an expected result. The evaluation of their own capacity therefore influences the motivation, initiation, participation and adherence to health care and, therefore, the control of diabetes. ${ }^{8}$

In order to improve knowledge of the disease as well as to ensure the capillary blood glucose targets are achieved, health education is of paramount importance and the affirmation of such through telephone, email and messaging contact has been a tool to improve the expected results. ${ }^{9} 10$ Poor blood glucose control during the pregnancy of patients diagnosed with GDM will be reflected in deleterious effects to the pregnant woman and the fetus. The better the control of blood glucose, the better the monitoring of the pregnancy, because its values are the basis for monitoring GDM during prenatal care. ${ }^{11-14}$ Studies affirm that special care, such as the attention that can be provided through telephone contact, encourages the participation of patients, as if making a sense of responsibility for the care of their own health arise. When patients are motivated, control over their health care is improved.

It has also been reported that the various forms of telemedicine are useful for diabetic patients in managing their disease, increasing the level of satisfaction with health care. ${ }^{15}$ Various studies report acceptance of telemedicine by patients as being high. ${ }^{16-18}$

The descriptions produced report that more frequent contact with their own health affects patient adherence and self-monitoring activities. ${ }^{19}$ One study reported that patients with diabetes who received a more welcoming service were more likely to perform preventive measures, selfcare and better blood glucose control than patients without such attention. ${ }^{20}$ The importance of planning education groups for people with diabetes is justified because, despite the great technological advances in relation to diagnosis and treatment, a high percentage of people do not adhere to the recommended treatment. ${ }^{21}$ This data was confirmed in this study, because after receiving instructions from the multidisciplinary group, adherence to the proposed treatment was observed in most patients, who were able to perform capillary blood glucose tests at home.

Some articles have shown that the level of acceptance of the disease has a positive or negative influence depending on the degree of understanding of the disease. The better the acceptance of the disease, the more effective the patient's performance, not only in relation to accession to control of blood glucose. ${ }^{22-25}$ Groups that present low acceptance of the disease also present inadequate control of blood glucose. The level of acceptance of the patient with diabetes and situations related to their routine have a direct influence on blood glucose levels and adherence to treatment. The results described in this study confirm that the use of the glucose meter as a tool, used by the patients themselves to determine capillary blood glucose after a multidisciplinary workshop, in which trained and qualified professionals provide instructions and effective information for secure adherence to treatment, results in good acceptance of the proposed treatment. ${ }^{26}$

During telephone contact, patients were questioned about possible difficulties in performing self-testing of blood glucose, and twenty-one patients responded that there was difficulty. Other factors cited as causing difficulty include: obtaining lancets, times, fear, pain, understanding the results and the amount of blood. These results are similar to those described by Pena et al., ${ }^{25}$ who evaluated non-pregnant patients with type 2 diabetes. ${ }^{25}$ The issue of not being able to obtain lancets was not one of the factors cited by patients and demonstrates the difficulties in our health system that need to be faced.

Questioned about difficulties in the realization of capillary blood glucose, $63 \%$ of patients responded that it was easy (degree of difficulty 0 ) and $9 \%$ reported level 4 or 5 . Another relevant fact is that the greater the discomfort the greater the difficulty in performing the cap- 
illary blood glucose test. Studies have shown that the glucose meter is an effective tool for control of blood glucose, useful for the monitoring and prevention of complications from diabetes, such as hypoglycemia and hyperglycemia. ${ }^{1}$ To achieve the best results, it is essential that patients are able to properly use the glucose meter and receive guidance for the interpretation of the values and minimize the difficulties encountered. The frequency and times at which the device should be used must be oriented due to the personal needs and goals established for the treatment of each patient. ${ }^{27,28}$ Some factors that might hinder the use of the glucose meter found in relevant literature confirm the results of this study: the amount of blood to be placed in the glucose meter and problems in handling of the device. ${ }^{29}$ Fear of carrying out self-monitoring of blood glucose was one of the variables mentioned among the patients who reported having some difficulty in using the glucose meter. Studies describe the pain associated with the procedure in obtaining capillary blood is a limiting factor for the self-monitoring of blood glucose.$^{30}$ Note that the frequency of this complaint, in this study, was extremely low.

As for the aspects related to nutritional advice, adherence to health-promoting guidelines is one of the biggest challenges of health professionals. ${ }^{31}$ Diet has shown an important regulatory role in the control of blood glucose, which makes the value of the food intake of utmost importance at a stage of life in which habits are already fairly consolidated. Adherence to treatment has been a challenge and this phenomenon is also the object of study. ${ }^{32}$ Dietary guidance is extremely important to GDM, because it consists of an initial treatment and enables appropriate weight gain and effective metabolic control. ${ }^{1}$ To raise awareness among pregnant women with respect to their nutrition and food intake, it is essential to a reorganize eating habits promoting better control of diabetes. As such, there needs to be integration between food intake and the other care performed by the patient. Dietary behavior is modified according to the requirements and limitations imposed by the characteristic of the disease. Food choices should be reviewed, adapting the calories to prevent excessive weight gain, reducing the intake of fats, spacing meals, guided moderate or light physical activity, when feasible, and blood glucose monitoring, aimed at control of the disease..$^{33}$ In this study, it was found that $19.7 \%$ of patients were not following the diet or were not spacing meals. However, when questioned about sugar intake, $38 \%$ of the pregnant women reported having consumed a food containing this substance. Studies conducted in non-pregnant diabetic patients also referred to difficulties in adherence to dietary guidelines and spaced meals..$^{32,34,35}$

The perception of patients in relation to possible food that may have increased capillary blood glucose corroborates studies that demonstrate the educational role of selfmonitoring in control of diabetes, an extremely relevant fact, mainly in GDM in which there is little time for the changes in lifestyle. ${ }^{1}$ As a short and highly significant period for the patient, their adherence to the proposed treatment was higher than in studies with non-pregnant women. This is because pregnant women feel responsible for the fetus and the outcome of their pregnancy. ${ }^{36}$

During the telephone call, we asked whether there were any queries or need for new guidance. Variables such as reference values, hyper and hypoglycemia and identifying foods with sugar were some doubts mentioned and that are found in the literature as being the greatest difficulty among diabetic patients. ${ }^{37}$ It is worth reiterating that the diagnosis of the disease often results in emotional shock for pregnant women who are not prepared to live with the limitations arising from the disease. Thus, the experience of diabetes breaks the organic harmony of the pregnancy, which is a unique and special period in the life of the woman. Having to change living habits that are already consolidated and assume a routine that involves the strict discipline of food planning, incorporation of or increased physical activity and blood glucose controls imposes the need to get in touch with feelings, desires, beliefs and attitudes that were unknown beforehand. Lifestyle modification does not take place magically but over the course of a journey that involves rethinking one's life and re-evaluating expectations of the future.

In this study we found large-scale adherence, as a whole, with the guidelines provided by the multidisciplinary team, highlighting once again the importance of an adequate follow-up and explanation of the clinical condition to the patient, as also described by other authors. ${ }^{38,39}$

\section{Conclusion}

It was observed that after participating in a multidisciplinary group there was good adherence among patients to the treatment proposed, especially in relation to selfmonitoring of blood glucose. The results related to nutritional control indicate the need to provide better clarification for patients on the importance of nutrition in the control of diabetes and the constant monitoring of such pregnant women regarding this aspect, which is known to present greater resistance to change. 


\section{Resumo}

Avaliação da retenção de informações e da adesão ao tratamento em pacientes com diabetes mellitus gestacional após grupo multiprofissional

Objetivo: avaliar a retenção de informações, após participação em grupo multiprofissional, em pacientes com diabetes mellitus gestacional (DMG), por meio de contato telefônico.

Método: foram incluídas 122 gestantes com diagnóstico de DMG. Após o diagnóstico, as pacientes eram encaminhadas ao grupo multiprofissional para receber orientações médicas, nutricionais e de enfermagem relacionadas à doença. Após três dias, as pacientes receberam um contato telefônico de um enfermeiro, que realizou perguntas relacionadas às informações recebidas. Na análise estatística, os resultados foram apresentados em frequências absolutas e relativas.

Resultados: a maioria das pacientes, 119/122 (97,5\%), estava conseguindo fazer a automonitorização glicêmica. Vinte e uma pacientes $(17,2 \%)$ referiram ter dificuldades para realizar a glicemia capilar, sendo a principal relacionada às lancetas. Quanto à dieta proposta, 24/122 (19,7\%) referiram que não estavam conseguindo cumprir; o fracionamento da dieta não foi alcançado por 23/122 (18,9\%) das gestantes e 47 (38,5\%) relataram ter ingerido açúcar nos dias seguintes à orientação do grupo multiprofissional.

Conclusão: em relação ao tratamento proposto, houve boa adesão das pacientes, especialmente quanto à automonitorização glicêmica. Em relação aos controles nutricionais, observamos maior dificuldade no seguimento das orientações, mostrando haver necessidade de seguimento em longo prazo e de fornecer melhor esclarecimento às pacientes sobre a importância da nutrição no controle do diabetes.

Palavras-chave: diabetes gestacional, equipe de assistência ao paciente, automonitorização da glicemia, educação alimentar e nutricional.

\section{RefEREnCES}

1. International Association of Diabetes and Pregnancy Study Groups Consensus Panel, Metzger BE, Gabbe SG, Persson B, Buchanan TA, Catalano $\mathrm{PA}$, et al. International association of diabetes and pregnancy study groups recommendations on the diagnosis and classification of hyperglycemia in pregnancy. Diabetes Care. 2010; 33(3):676-82.

2. Reader D, Splett P, Gunderson EP; Diabetes Care and Education Dietetic Practice Group. Impact of gestational diabetes mellitus nutrition practice guidelines implemented by registered dietitians on pregnancy outcomes. J Am Diet Assoc. 2006; 106(9):1426-33.
3. Ayach W, Calderon Ide M, Rudge MV, Costa RA. [Comparison between two gestational diabetes screening tests and the perinatal outcome]. Rev Bras Ginecol Obstet. 2010; 32(5):222-8.

4. Ayach W, Rudge MVC, Costa RAA. Associação glicemia de jejum e fatores de risco como teste para rastreamento do diabete gestacional. Rev Bras Saúde Matern Infant. 2005; 5(3):329-35.

5. Detsch JCM, Bortolini LGC, Ravazzani AC, Nascimento DJ, Oliveira FCJ, Réa RR. Marcadores para o diagnóstico e tratamento de 924 gestações com diabetes melito gestacional. Arq Bras Endocrinol Metabol. 2011; 55(6):389-98.

6. Leary J, Pettitt D, Jovanovic L. Gestational diabetes guidelines in a HAPO world. Best Pract Res Clin Endocrinol Metab. 2010; 24(4):673-85.

7. Sociedade Brasileira de Endocrinologia e Metabologia. Diabetes mellitus gestacional. Rev Assoc Med Bras. 2008; 54(6):477-80.

8. Po YM. Telemedicine to improve patients' self-efficacy in managing diabetes. J Telemed Telecare. 2000; 6(5):263-7.

9. Shultz EK, Bauman A, Hayward M, Holzman R. Improved care of patients with diabetes through telecommunications. Ann N Y Acad Sci. 1992; 670:141-5.

10. Ahring KK, Ahring JP, Joyce C, Farid NR. Telephone modem access improves diabetes control in those with insulin-requiring diabetes. Diabetes Care. 1992; 15(8):971-5.

11. Kim HS, Kim S. [Effects of an integrated self-management program on selfmanagement, glycemic control, and maternal identity in women with gestational diabetes mellitus]. J Korean Acad Nurs. 2013; 43(1):69-80.

12. Ferrara A, Hedderson MM, Albright CL, Brown SD, Ehrlich SF, Caan BJ, et al. A pragmatic cluster randomized clinical trial of diabetes prevention strategies for women with gestational diabetes: design and rationale of the Gestational Diabetes' Effects on Moms (GEM) study. BMC Pregnancy Childbirth. 2014; 14:21-29.

13. Kim C, McEwen LN, Kerr EA, Piette JD, Chames MC, Ferrara A, et al. Preventive counseling among women with histories of gestational diabetes mellitus. Diabetes Care. 2007; 30(10):2489-95.

14. Ferrara A, Peng T, Kim C. Trends in postpartum diabetes screening and subsequent diabetes and impaired fasting glucose among women with histories of gestational diabetes mellitus: A report from the Translating Research Into Action for Diabetes (TRIAD) Study. Diabetes Care. 2009; 32(2):269-74.

15. Polonsky WH, Anderson BJ, Loher PA. Assessment of diabetes-specific distress. Diabetes Care. 1995; 18(6):754-60.

16. Allen A, Hayes J. Patient satisfaction with teleoncology: a pilot study. Telemed J. 1995; 1(1):41-6.

17. McKay HG, Feil EG, Glasgow RE, Brown JE. Feasibility and use of an Internet support service for diabetes self-management. Diabetes Educ. 1998; 24(2):174-9.

18. Johnston B, Wheeler L, Deuser J, Sousa KH. Outcomes of the Kaiser Permanente Tele-Home Health Research Project. Arch Fam Med. 2000; 9(1):40-5.

19. Farris C. Diagnóstico e rastreamento do diabete melito gestacional. Arq Catarin. Med. 2012; 41(1):68-71.

20. O'Connor PJ, Desai J, Rush WA, Cherney LM, Solberg LI, Bishop DB. Is having a regular provider of diabetes care related to intensity of care and glycemic control? J Fam Pract. 1998; 47(4):290-7.

21. Cazarini RP, Zanetti ML, Ribeiro KP, Pace AM, Foss MC. Adesão a um grupo educativo de pessoas portadoras de diabetes mellitus: porcentagem e causas. Medicina (Ribeirão Preto). 2002; 35(2):142-150.

22. Glasgow RE, Ruggiero L, Eakin EG, Dryfoos J, Chobanian L. Quality of life and associated characteristics in a large national sample of adults with diabetes. Diabetes Care. 1997; 20(4):562-7.

23. Anderson RJ, Freedland KE, Clouse RE, Lustman PJ. The prevalence of comorbid depression in adults with diabetes: a meta-analysis. Diabetes Care. 2001; 24(6):1069-78.

24. Jacobson AM, De Groot M, Samson JA. The evaluation of two measures of quality of life in patients with type I and type II diabetes. Diabetes Care. 1994; 17(4):267-74

25. Pena BC, Xavier TVH, Pimentel MGG, Campos MC, Câmara AMCS, Diniz LM. Perfil dos pacientes diabéticos do tipo 2, insulino-necessitantes, receptores de kits para monitoração glicêmica e tratamento, vinculados a um Centro de Saúde de Belo Horizonte. Rev Med Minas Gerais. 2012; 22(4):388-95.

26. Maia FF, Araújo LR. Acurácia, efeitos na terapia insulínica e controle glicêmico e complicações do sistema de monitorização contínua da glicose em pacientes com diabetes mellitus tipo 1. Arq Bras Endocrinol Metab. 2005; 49(4):563-8. 
27. Kendall DM, Kaplan RA, Paulson CF, Parkes JL, Tideman AM. Accuracy and utility of a 10-test disk blood glucose meter. Diabetes Res Clin Pract. 2005; 67(1):29-35.

28. Clement S. Guidelines for glycemic control. Clin Cornerstone. 2004; 6(2):31-9

29. Mira GS, Candido LMB, Yale JF. Performance de glicosímetro utilizado no automonitoramento glicêmico de portadores de diabetes mellitus tipo 1 Arq Bras Endocrinol Metabol. 2006; 50(3):541-9.

30. Ferraz DP, Maia FF, Araújo LR. Fingerstick capillary glycemia versus ear lobe measurement: comparative analysis of results and patient preferences. Arq Bras Endocrinol Metabol. 2004; 48(3):389-93.

31. Domingues PC, Neri AL. Atividade física habitual, sintomas depressivos e doenças auto-relatadas em idosos da comunidade. Rev Bras Ativ Fis Saúde. 2009; 41:164-73

32. Pontieri FM, Bachio MM. Crenças de pacientes diabéticos acerca da terapia nutricional e sua influência na adesão ao tratamento. Ciênc Saúde Coletiva. 2010; 15(1):51-160.

33. Sociedade Brasileira de Diabetes. Diabetes mellitus gestacional: diagnóstico, tratamento e acompanhamento pós gestacional. Diretrizes da Sociedade Brasileira de Diabetes. São Paulo, 2014.
34. Gomes-Villas LCB, Foss MC, Foss-Freitas MC, Torres HC, Monteiro LZ, Pace AE. Adesão à dieta e ao exercício físico das pessoas com diabetes mellitus. Texto Contexto Enferm. 2011;20(2):272-9.

35. Rosenstock IM. Historical origins of the health belief model. Health Educ Monogr. 1974; 2(4):328-35

36. Santos AFL, Araújo JWG. Food practice and diabetes: challenge to surveillance in health. Epidemiol Serv Saúde. 2011; 20(2):255-63.

37. Santos MLN. A percepção do portador de diabetes mellitus sobre sua patologia, tendo como base as reuniões educativas. Rev Digital EFDeportes. 2012; 17(167):167-73

38. Ferraz AEP, Zanetti ML, Brandão ECM, Romeu LC, Foss MC, Paccola GMGF, et al. Atendimento multiprofissional ao paciente com diabetes mellitus no Ambulatório de Diabetes do HCFMRP-USP. Medicina (Ribeirão Preto). 2000; 33(2):170-1.

39. Péres DS, Santos MA, Zanetti ML, Ferronato AA. Dificuldades dos pacientes diabéticos para o controle da doença: sentimentos e comportamentos. Revista Latinoam Enferm. 2007; 15(6):1105-12.

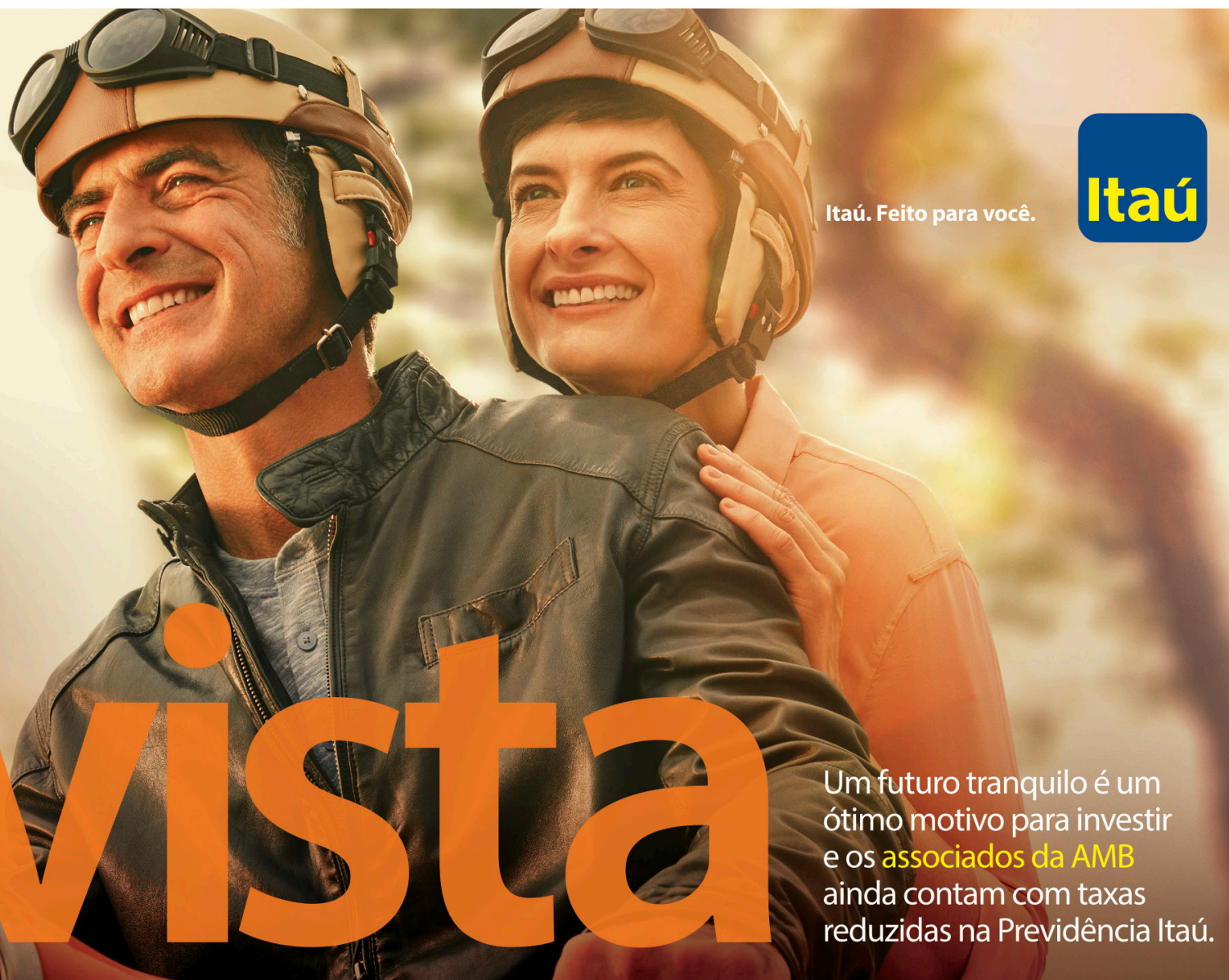

Todo mundo tem um motivo para investir. Qual é o seu?
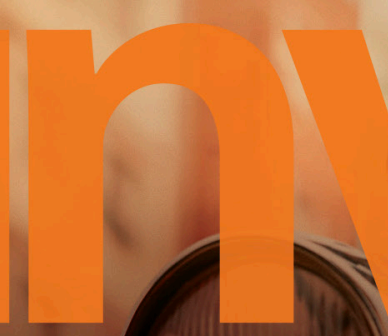

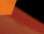

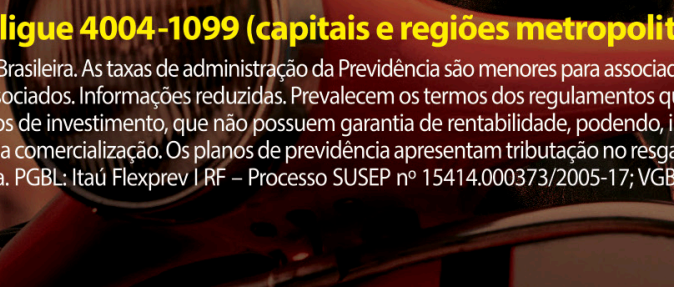

(demais localidades) em dias úteis, das $8 \mathrm{~h}$ às $20 \mathrm{~h}$.

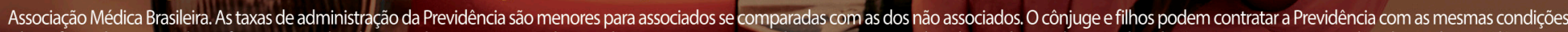

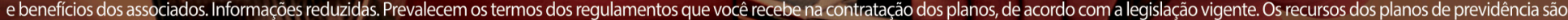

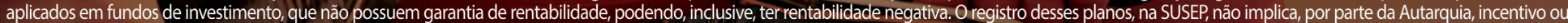

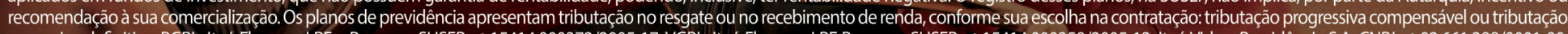

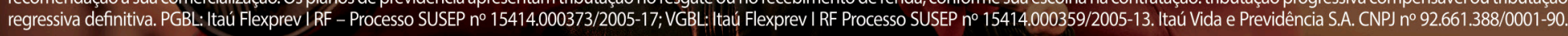

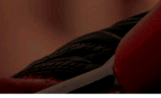

